\title{
SEASONAL DYNAMICS OF BEAN APHIDS AND ITS RELATIONSHIP WITH THE ABUNDANCE OF LADY BIRD BEETLES
}

\author{
Mohsen Ara Sharmin, Md. Ruhul Amin*, Md Ramiz Uddin Miah and Abdul \\ Mannan Akanda ${ }^{1}$ \\ Department of Entomology, Bangabandhu Sheikh Mujibur Rahman Agricultural \\ University, Gazipur 1706, Bangladesh
}

\begin{abstract}
The seasonal dynamics of aphid Aphis craccivora Koch (Hemiptera: Aphididae) on four bean species namely country bean Lablab purpureus, yard long bean Vigna sesquipedalis, hyacinth bean Dolichos lablab and bush bean Phaseolus vulgaris were studied from September to December 2017 in the experimental field of the Department of Entomology, Bangabandhu Sheikh Mujibur Rahman Agricultural University, Gazipur, Bangladesh. The study also investigated the relationship between the abundance of aphid and its predatory insect lady bird beetle. Aphid abundance on the bean species showed increasing trend from the $4^{\text {th }}$ week of September and reached to the peak during the $2^{\text {nd }}$ week of November and then declined. Bush bean and yard long bean, respectively depicted the higher and lower abundances of aphid throughout the study. Relationship between the abundance of aphid and lady bird beetle on the bean species were positively correlated. Aphid showed negatively correlation with temperature and rainfall, and positive correlation with relative humidity, and the correlations were not significant. Multiple regression equation showed that temperature had the highest effect which contributed $16.1-19.2 \%$ role on the population of aphid.
\end{abstract}

Key words: Abundance, Aphis craccivora, bean, lady bird beetle

\section{INTRODUCTION}

The country bean Lablab purpureus, yard long bean Vigna sesquipedalis, hyacinth bean Dolichos lablab and bush bean Phaseolus vulgaris are important vegetables and income generating crops in Bangladesh. These vegetables are also cultivated for fodder and cover crop. The main obstacle to bean production in Bangladesh is the infestation of aphid Aphis craccivora Koch (Hemiptera: Aphididae). This polyphagous insect causes serious damage on bean plants from seedling to the pod-bearing stage.

*Author for corresponding: <mramin@bsmrau.edu.bd>, ${ }^{1}$ Department of Plant Pathology, Bangabandhu Sheikh Mujibur Rahman Agricultural University, Gazipur 1706, Bangladesh. (C)2020 Zoological Society of Bangladesh DOI: https://doi.org/10.3329/bjz.v48i2.52375 
Aphids feed on phloem sap and their feeding injury reduce branching and the infested plants become stunted, suffer from withering of flowers and produce lower quantity of pods (Beckendorf et al. 2008). Aphids also play vital role in the transmission of necrotic yellow, mosaic yellow and leaf roll viruses in bean plants (Smith and Boyko 2007). Aphid infestation level varies among the crop species and different growth stages of the same species.

Abundance and infestation of aphid are linked to characteristics of host plants and prevailing weather parameters (Amin et al. 2017). Mandal et al. (2018) reported that temperature, light intensity and relative humidity solely or collectively affect the abundance of aphid on mustard, and they observed that temperature had greater effect than other factors.

Aphid population dynamics are believed to be under the control of a number of natural enemies and the coccinellids are the most abundant and effective predators of aphids (Liu et al 2004, Miao et al. 2007). Costamagna and Landis (2006) found that predator insects prevent aphid population growth and reduce the established population. Information on the seasonal dynamics of aphid on different bean species, relationship with meteorological parameters and natural enemy like lady bird beetle would be an understanding of the abundance of pest and predator insects. Such message may be helpful in selecting suitable bean species for cultivation and implementation of integrated management program of aphid in appropriate time.

\section{MATERIAL AND METHODS}

The study was conducted in the experimental field and laboratory of the Department of Entomology, Bangabandhu Sheikh Mujibur Rahman Agricultural University, Gazipur, Bangladesh during September to December 2017 with four bean species namely country bean Lablab purpureus variety BARI Seem 1, yard long bean Vigna sesquipedalis variety BARI Borboti 1, hyacinth bean Dolichos lablab variety BARI Seem 6, and bush bean Phaseolus vulgaris variety BARI Jar bean 3 .

Climatic conditions of the experimental location: The experimental area is surrounded by sale, Shorea robusta Gaertn forest and characterized by a welldefined dry season (February to May), rainy season (June to September) and short winter (December and January). Annual mean of maximum and minimum temperatures, relative humidity and rainfall are 36.0 and $12.7{ }^{\circ} \mathrm{C}, 65.8 \%$ and $237.6 \mathrm{~cm}$, respectively.

Cultivation of bean plants: The bean plants were cultivated following randomized complete block design having plot size $3.0 \times 2.0 \mathrm{~m}$ with three replications. The spacing between block to block and plot to plot was $0.5 \mathrm{~m}$ and 
$1.0 \mathrm{~m}$, respectively. Fertilizers were applied according to Fertilizer Recommendation Guide (FRG 2012). The seeds were collected from the Horticulture Research Center, Bangladesh Agricultural Research Institute, Joydebpur, Gazipur and sown on 01 September 2017. Each plot contained one row with 5 pits apart from $60 \mathrm{~cm}$. After emergence of seedlings, the plants were supported by bamboo sticks to facilitate creeping. The crops were exposed to aphid infestation and pod borer was managed mechanically. Other intercultural operations were done whenever necessary.

Insect population study: Weekly observations were started after two weeks of sowing. For each sample plant, the number of aphids on the top shoot (two apical leaves) was counted. In every inspection, the number of lady bird beetle per plant was counted.

Collection of weather data: The daily mean temperature, relative humidity and rainfall data were collected from the weather station of BSMRAU, Gazipur and calculated for standard meteorological week data.

Data analysis: Pearson's correlation and multiple regression were used to analyze the data. All the analyses were performed using IBM SPSS 21.0 (IBM SPSS statistics 21, Georgia, USA).

\section{RESULTS AND DISCUSSION}

Aphid abundance on the tested bean species throughout the season showed fluctuations (Figure 1). Aphid population showed increasing trend from the $4^{\text {th }}$ week of September and reached to the peak in the $2^{\text {nd }}$ week of November and then declined on all the bean species. The number of aphid population per top shoot was found to be the highest (34.0/shoot) on yard long bean followed by country bean, hyacinth bean and bush bean (23.7, 21.3 and 17.0/shoot, respectively) on 17 November. The emergence of aphid population was associated with juvenile stage of the plants. Variations in weather conditions and time of the season also affected population dynamics of the aphid. Amjad et al (2009) observed the population abundance of sucking insects on five cotton cultivars and found significant variations in population abundance with time of the season. The meteorological conditions in the month of November may attribute to enhance the rate of development and reproduction of aphids on the bean species.

Predatory insect, lady bird beetle was observed on the bean plants simultaneously with aphid abundance. Relationship between aphid and lady bird beetle abundance had significant positive correlation on all the bean species (Figure 2a: $\mathrm{y}=0.084+0.055 \mathrm{x}, \mathrm{r}=0.583, \mathrm{~F}_{1,31}=16.0, \mathrm{p}<0.001$; Figure $2 \mathrm{~b}: \mathrm{y}=$ $0.115+0.068 \mathrm{x}, \mathrm{r}=0.647, \mathrm{~F}_{1,31}=22.4, \mathrm{p}<0.001$; Figure 2c: $\mathrm{y}=0.085+0.062 \mathrm{x}$, $\mathrm{r}=0.497, \mathrm{~F}_{1,31}=10.2, \mathrm{p}<0.01 ;$ Figure $2 \mathrm{~d}: \mathrm{y}=0.006+0.058 \mathrm{x}, \mathrm{r}=0.513, \mathrm{~F}_{1,31}=$ 
$11.1, \mathrm{p}<0.01)$. The results of the present study are in agreement with Hossain et al. (2013) who reported that predator abundances on cotton were positively

Table 1. Correlation coefficients ( $r$ values) of the abundance of aphid on different bean plants with weather parameters

\begin{tabular}{|c|c|c|c|}
\hline \multirow[t]{2}{*}{ Bean plant } & \multicolumn{3}{|c|}{ Weather parameters } \\
\hline & $\begin{array}{c}\text { Temperature } \\
\left({ }^{\circ} \mathrm{C}\right)\end{array}$ & $\begin{array}{c}\text { Relative } \\
\text { humidity (\%) }\end{array}$ & $\begin{array}{c}\text { Rainfall } \\
(\mathrm{mm})\end{array}$ \\
\hline Country bean & $-0.438^{N S}$ & $0.542 \mathrm{NS}$ & $-0.450 \mathrm{NS}$ \\
\hline Yard long & & & \\
\hline bean & $-0.401 \mathrm{NS}$ & $0.536 \mathrm{NS}$ & $-0.480 \mathrm{NS}$ \\
\hline Bush bean & $-0.418 \mathrm{NS}$ & 0.494 NS & --0.474 NS \\
\hline $\begin{array}{l}\text { Hyacinth } \\
\text { bean }\end{array}$ & $-0.431^{\mathrm{NS}}$ & $0.532 \mathrm{NS}$ & $-0.474 \mathrm{NS}$ \\
\hline
\end{tabular}

Table 2. Multiple regression models along with coefficients of determination $\left(R^{2}\right)$ regarding the effect of weather parameters on the abundance of aphid on different bean plants during September to December, 2017

\begin{tabular}{|c|c|c|c|c|c|}
\hline $\begin{array}{l}\text { Bean } \\
\text { plant }\end{array}$ & Regression equation & $\mathbf{R}^{2}$ & $100 \mathbf{R}^{2}$ & $\begin{array}{c}\text { Role of } \\
\text { individual } \\
\text { factor }\end{array}$ & F statistic \\
\hline \multirow{3}{*}{$\begin{array}{l}\text { Country } \\
\text { bean }\end{array}$} & $\mathrm{Y}=43.021-1.127 \mathrm{X}_{1}$ & 0.192 & 19.2 & 19.2 & $\mathrm{~F}_{1,8}=1.9, \mathrm{p}=0.21$ \\
\hline & $Y=-215.981+0.345 X_{1}+2.499 X_{2}$ & 0.298 & 29.8 & 10.6 & $\mathrm{~F}_{2,7}=1.5, \mathrm{p}=0.29$ \\
\hline & $\begin{array}{l}Y=-195.852+0.491 X_{1}+2.238 X_{2-} \\
0.087 X_{3}\end{array}$ & 0.363 & 36.3 & 6.5 & $\mathrm{~F}_{3,6}=1.1, \mathrm{p}=0.41$ \\
\hline \multirow{3}{*}{$\begin{array}{l}\text { Yard long } \\
\text { bean }\end{array}$} & $\mathrm{Y}=46.423-1.170 \mathrm{X}_{1}$ & 0.161 & 16.1 & 16.1 & $\mathrm{~F}_{1,8}=1.5, \mathrm{p}=0.25$ \\
\hline & $Y=-296.439+0.778 X_{1}+3.308 X_{2}$ & 0.305 & 30.5 & 14.4 & $\mathrm{~F}_{2,7}=1.5, \mathrm{p}=0.28$ \\
\hline & $\begin{array}{l}Y=-269.683+0.973 X_{1}+2.962 X_{2-}^{-} \\
1.073 X_{3}\end{array}$ & 0.394 & 39.4 & 8.9 & $\mathrm{~F}_{3,6}=1.3, \mathrm{p}=0.36$ \\
\hline \multirow[t]{3}{*}{ Bush bean } & $\mathrm{Y}=32.645-0.850 \mathrm{X}_{1}$ & 0.174 & 17.4 & 17.4 & $\mathrm{~F}_{1,8}=1.7, \mathrm{p}=0.23$ \\
\hline & $\begin{array}{l}Y= \\
86.546+267.310 X_{1}+353.856 X_{2}\end{array}$ & 0.245 & 24.5 & 7.1 & $\mathrm{~F}_{2,7}=1.1, \mathrm{p}=0.38$ \\
\hline & $\begin{array}{l}Y=-115.165+0.232 X_{1}+1.365 X_{2^{-}} \\
0.750 X_{3}\end{array}$ & 0.334 & 33.4 & 8.9 & $\mathrm{~F}_{3,6}=1.0, \mathrm{p}=0.45$ \\
\hline \multirow{3}{*}{$\begin{array}{l}\text { Hyacinth } \\
\text { bean }\end{array}$} & $\mathrm{Y}=38.825-1.010 \mathrm{X}_{1}$ & 0.186 & 18.6 & 18.6 & $\mathrm{~F}_{1,8}=1.8, \mathrm{p}=0.21$ \\
\hline & $\mathrm{Y}=-190.421+0.293 \mathrm{X}_{1}+2.212 \mathrm{X}_{2}$ & 0.287 & 28.7 & 10.1 & $\mathrm{~F}_{2,7}=1.4, \mathrm{p}=0.31$ \\
\hline & $\begin{array}{l}Y=-169.857+0.443 X_{1}+1.946 X_{2-} \\
0.825 X_{3}\end{array}$ & 0.368 & 36.8 & 8.1 & $\mathrm{~F}_{3,6}=1.2, \mathrm{p}=0.40$ \\
\hline
\end{tabular}

correlated with the abundances of prey. The higher prey density favors the predators to have enough food with easy and convenient environment. Plant morphological attributes like architecture, canopy, leaf hairs and trichomes also affect the abundance of pest and predator insects (Raghu et al. 2004). In the present study, lady bird beetle was found from the beginning of the abundance of aphid and they showed variations in their abundance among the bean species. The variations of the growth stages, morphological structures like canopy, leaf hairs and trichomes of the bean species may impair the activity of the pest and predators. Amin et al. (2016) reported that feeding efficiency, 
survival, growth and development of pest insects and their population abundance are affected by the morphological features and nutrient contents in host plants.

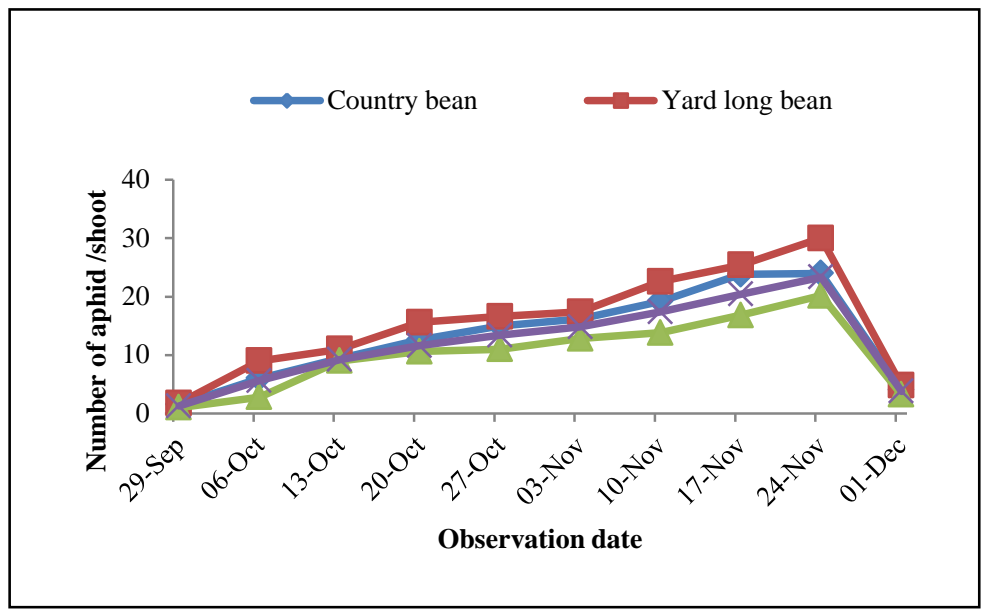

Fig. 1. Abundance of aphid per top shoot of four bean species at different dates during September to December 2017.
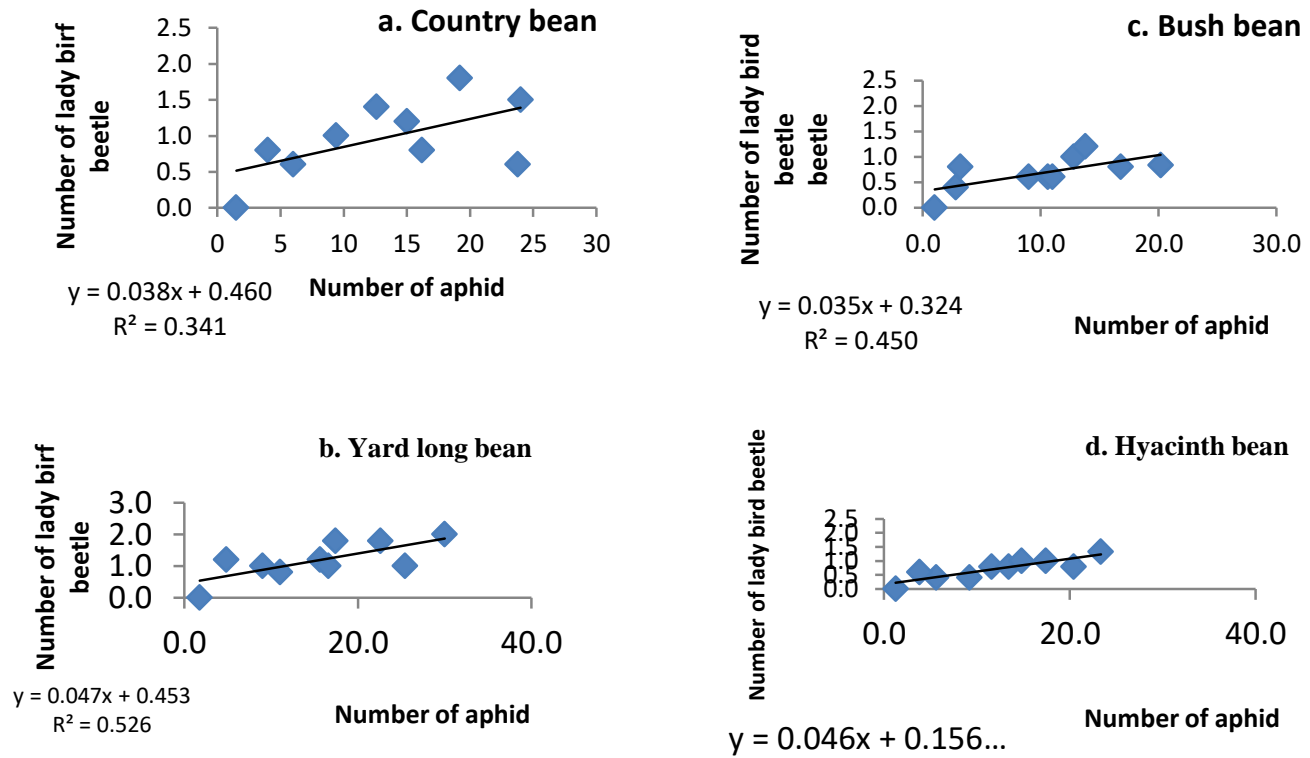

Fig. 2. Relationship between the abundance of aphid and lady bird beetle on four bean species.

Table 1 showed that weather parameters showed insignificant effect on the abundance of aphid on the bean species and the relationship was negatively 
correlated with temperature and rainfall, and positively correlated with relative humidity (Country bean- temperature: $\mathrm{F}_{1,8}=1.9, \mathrm{p}=0.21$, relative humidity: $\mathrm{F}_{1,8}$ $=3.3, \mathrm{p}=0.11$, rainfall: $\mathrm{F}_{1,8}=2.0, \mathrm{p}=0.19$; yard long bean- temperature: $\mathrm{F}_{1,8}=$ 1.5, $\mathrm{p}=0.25$, relative humidity: $\mathrm{F}_{1,8}=3.2, \mathrm{p}=0.11$, rainfall: $\mathrm{F}_{1,8}=2.4, \mathrm{p}=0.16$; bush bean- temperature: $\mathrm{F}_{1,8}=1.7, \mathrm{p}=0.23$, relative humidity: $\mathrm{F}_{1,8}=2.6, \mathrm{p}=$ 0.15 , rainfall: $\mathrm{F}_{1,8}=2.3, \mathrm{p}=0.17$; hyacinth bean- temperature: $\mathrm{F}_{1,8}=1.8, \mathrm{p}=$ 0.21 , relative humidity: $F_{1,8}=3.2, p=0.11$, rainfall: $F_{1,8}=2.4, p=0.17$ ). Multiple regression equation showed that the individual effect of temperature, relative humidity and rainfall revealed $16.1-19.2 \%, 7.1$ to $14.4 \%$ and 6.5 to $8.9 \%$ fluctuation of aphid on the bean species (Table 2). Temperature with relative humidity exerted 24.5 - 30.5\%, and combined effect of all the weather parameters were $39.4,36.8,36.3$ and $33.4 \%$ on yard long bean, hyacinth bean, country bean and bush bean, respectively, but none of the equation was found to be significant (Table 3).

The present study showed that aphid exerted fluctuations in their population on the cultivated bean plants during the study and the fluctuations were related to prevailed weather parameters. The findings showed agreement with Sharma et al. (2013) who reported that aphid population on tomato was positive but not significantly correlated with the maximum temperature, and negative but not significantly correlation with rainfall. Effect of weather parameters on the abundance of aphid varies with crop species and geographical locations which is in accordance with Mahmood et al. (1990) who observed $73.0 \%$ contribution of weather parameters on the population fluctuation of aphid on okra plants. The results of the present study depicted variations in the abundance of aphid on four bean species and showed significantly positive correlation between the populations of aphid and its natural enemy like lady bird beetle. The findings of the study also indicated the particular and combined effect of weather parameters on the population dynamics of aphid on different bean species. These findings could be helpful to growers for implementation of integrated pest management program at proper time to manage aphid in bean fields.

Acknowledgement: Authors are grateful to the University Grants Commission of Bangladesh for funding the study.

\section{LITERATURE CITED}

AMIN, M.R., AFRIN, R., ALAM, M.Z., HOSSAIN, M.M. and KWON, Y.J. 2017. Effect of leaf trichomes and meteorological parameters on population dynamics of aphid and jassid in cotton. Bangladesh J. Agril. Res. 42: 13-25. 
AMIN, M.R., AFRIN, R., SUH, S.J. and KWON. Y.J. 2016. Infestation of sucking insect pests on five cotton cultivars and their impacts on varietal agronomic traits, biochemical contents, yield and quality. SAARC J. Agric. 1: 11-23.

AMJAD, M., BASHIR, M.H. and AFZAL, M. 2009. Comparative resistance of some cotton cultivars against sucking insect pests. Pak. J. Soc. Life Sci. 7: 144-147.

BECKENDORF, E.A., CATANGUI, M.A. and RIEDELL, W.E. 2008. Soybean aphid feeding injury and soybean yield, yield components, and seed composition. Agron. J. 100: 237-246.

COSTAMAGNA, A.C. and LANDIS, D.A. 2006. Predators exert top-down control of soybean aphid across a gradient of agricultural management systems. Ecol. Appl. 16: 1619-1628.

FRG. 2012. Fertilizer Recommendation Guide. Bangladesh Agricultural Research Council, Farm Gate, Dhaka.

HOSSAIN, S.M.A., BAQUE, M.A. and AMIN, M.R. 2013. Comparative effectiveness of seed treating and foliar insecticides against sucking pests of cotton and impact on their natural enemies. Bangladesh J. Agril. Res. 38: 61-70.

LIU, J., WU, K., HOPPER, K.R. and ZHAO, K. 2004. Population dynamics of Aphis glycines (Homoptera: Aphididae) and its natural enemies in soybean in northern China. Ann. Entomol. Soc. Am. 97: 235-239.

MAHMOOD, T., KHOKHAR, K.M., BANARAS, M. and ASHRAF, M. 1990. Effect of environmental factors on the density of leaf hopper, Amrasca devastans (Distant) on okra. Trop. Pest Manag. 36: $282-284$.

MANDAL, E., AMIN, M.R., RAHMAN, H. and AKANDA, M.A. 2018. Infestation level and population dynamics of aphid on mustard. Bangladesh J. Agril. Res. 43: 611-618.

MIAO, J., WU, K., HOPPER, K.R. and LI, G. 2007. Population dynamics of Aphis glycines (Homoptera: Aphididae) and impact of natural enemies in northern China. Environ. Entomol. 36: 840-848.

RAGHU, S., DREW, R.A.I. and CLARKE, A.R. 2004. Influence of host plant structure and microclimate on the abundance and behavior of a tephritid fly. J. Insect Behav. 17: 179-190.

SHARMA, D., MAQBOOL, A., AHMAD, H., SRIVASTAVA, K., KUMAR, M., VIR, V. and JAMWAL. S. 2013. Effect of meteorological factors on the population dynamics of insect pests of tomato. Vegetable Sci. 40: 90-92.

SMITH, C. and BOYKO, E. 2007. The molecular bases of plant resistance and defense responses to aphid feeding: current status. Ent. Exp. Appl. 122: 1-16. 